\title{
The Mediating Effects of Organizational Learning on the Relationship between Knowledge Management and Organizational Performance: An Applied Study on the Egyptian Commercial Banks
}

\author{
Wageeh Nafei ${ }^{1}$ \\ ${ }^{1}$ University of Sadat City, Egypt \\ Correspondence: Wageeh Nafei, University of Sadat City, Menoufia, Egypt. E-mail: \\ dr.wageeh1965@yahoo.com
}

Received: December 3, 2013

Accepted: Decemberm 26, 2013

Online Published: January 23, 2014

doi:10.5539/ijbm.v9n2p244

URL: http://dx.doi.org/10.5539/ijbm.v9n2p244

\begin{abstract}
This study investigates the mediating significant role of OL in the relationship between Knowledge Management (KM) and Organizational Performance (OP). It intends to explore the significant role of KM in achieving superior OP. It analyzes how KM creates OL and how OL contributes to OP.

$\mathrm{KM}$ and OL should join forces and develop a unified discipline. KM needs OL and its expanding body of good research. OL needs base of practitioners of KM and its abiding interest in problems and practice.

$\mathrm{KM}$ and OP are believed to be essential for the success in business. Organizations and researchers have turned their attention to KM recently. Despite the growing interest and investment of resources in KM, there are few empirical studies to demonstrate the relationship between KM and OP. Understanding these relationships is essential for managers if they hope to improve OP through KM. The purpose of this research is to fill the abovementioned gap by testing the relationships between KM and their impact on OP.

This study was conducted on the Egyptian commercial banks. Of the 382 questionnaires that were distributed, 310 usable questionnaires were returned, a response rate of $81 \%$. This survey-type research is descriptive in terms of the data collection.

The finding reveals that KM affects OP through OL. Accordingly, the study provided a set of recommendations including the necessity to pay more attention to $\mathrm{KM}$ as a key source for organizations to enhance the competitive advantage which is of prime significance for OP through OL.
\end{abstract}

Keywords: knowledge management, organizational learning, organizational performance

\section{Introduction}

Knowledge Management (KM) is a process that transforms individual knowledge into organizational knowledge (Rašul, et al., 2012). KM is a process that helps organizations to find important information, select, organize and publish them; and it is a proficiency that will be necessary for actions like solving problems, dynamic learning, decision making (Nazari \& Emami, 2012).

$\mathrm{KM}$ does not belong to one area; people from different disciplines are working on it. Approaches to KM are still at emerging state and the process is ongoing, till we get a complete formal approach which shall be universally accepted (Anand \& Singh, 2011).

KM has emerged as one of the most important areas in management practices and established as a basic resource for firms and economies. KM is regarded as collection, distribution and efficient use of knowledge resources. It is a process of knowledge creation, validation, presentation, distribution and evaluation (Tahir et al., 2010).

$\mathrm{KM}$ is a process that helps achieve objectives and enhance organizational performance through creating, accumulating, organizing and utilizing knowledge. $\mathrm{KM}$ also consists of strategy, cultural values and workflow (Chen \& Huang, 2007).

KM uses systematic strategies to create value, discover knowledge, understand and use (Harry, 2006). KM is access to expertise, and knowledge that provides new capabilities, enables better performance, encourages development and innovation, and boosting customer value (Gloet \& Terziovski, 2004). 
KM processes are part of an organization's business processes (Zhou \& Fink, 2003). Its processes can help an organization acquire, store and use knowledge for tasks such as problem-solving, dynamic learning, strategic planning and decision-making (Sveiby, 1997).

Researchers interested in KM belong to different fields such as psychology, management, sociology, and economics. This means that $\mathrm{KM}$ is a multidisciplinary field. KM is a field of knowledge concerned with individuals, not technology, it is about all types of knowledge related to the activities of the organization and making it available to all employees, in order to achieve its objectives. This requires the need to focus on the form of knowledge which contributes to supporting and enhancing the value of public or private organizations, and improving Organizational Performance (OP) in the pursuit of competitive advantage for the organization in the long term (Wiig, 1997).

$\mathrm{KM}$ processes can help an organization acquire, store and use knowledge for tasks such as problem-solving, dynamic learning, strategic planning and decision-making (Sveiby, 1997). Despite the progress in the theoretical aspect of KM, there is still a need for further study and investigation to enrich the theoretical and applied research (Marques \& Simon, 2006).

The organization, which has a unit specializing in the development of KM, would be able to use its resources efficiently and effectively as that contributes to improving the quality of the product or service (Anantatmula, 2007; Choi et al., 2008; Zack, et al., 2009; Akroush \& Al-Mohammed, 2010).

In the Arab environment, this issue is still in its infancy. This reveals the importance of the present study theoretically and practically for analyzing how KM creates OL and how OL contributes to OP. Therefore, this study investigates the mediating role of OL in the relationship between KM and OP. Also, the current study seeks to inform officials at the Egyptian commercial banks about the importance of KM as a key source for organizations to enhance the competitive advantage which is of prime significance for OP through OL.

This paper is concerned with OL as a mediator of the relationship between KM and OP at the Egyptian commercial banks. It aims at recognizing the type and degree of the relationship between KM, OL and OP at the Egyptian commercial banks.

\section{Literature Review}

\subsection{The Relationship between KM and $O L$}

$\mathrm{KM}$ and $\mathrm{OL}$ are terms commonly used in today's business environment and usually associated with large budget projects pursued by firms convinced that the only competitive advantage the company of the future will have is its ability to learn faster than its competitors (DeGeus, 1988). OL has been regarded as one of the strategic means of archiving long-term organizational success (Senge, 1990). Recently, the analysis of OL has become an increasingly important area. OL has been considered, from a strategic perspective, as a source of heterogeneity among organizations, as well as a basis for a possible competitive advantage (Liao \& Wu, 2009).

OL will develop well drawing on well structured knowledge in different organizations. Business could have OL capabilities underlying well individual learning (Nonaka \& Takeuchi, 1995).

KM discusses different influences on OL in different organizations. Some researchers find these two focuses as cause and effect simultaneously, and some researchers take OL is a cause, KM is an effect; or opposite. In these studies, researchers implicitly assume a perspective of OL $\rightarrow \mathrm{KM}$ effect in which the causal direction runs primarily from OL to KM. And a KM $>$ OL effect could also account for the associations between KM and OL (Su, et al., 2003).

In order to develop learning abilities, organization should complete well KM process. Without KM, one organization can't develop personal or group learning abilities (Garratt, 1990, Su, et al., 2004). From literature review, the researcher found that KM has a significant impact on OL (Su, et al., 2004; Darroch, 2005).

As a viewpoint of system, Ke \& Wei (2006) identified KM as the antecedent and the base of OL. OL can be considered as a latent multidimensional construct including managerial commitment, systems perspective, openness and experimentation, and knowledge transfer and integration. Knowledge, along with its dissemination; has become a key strategic resource to OL. OL is seen as a dynamic process based on knowledge, which implies moving among the different levels of action, going from the individual to the group level, and then to the organizational level and back again. In this perspective, OL is viewed as a reaction to KM rather than an action that contributes to KM in the organizations (Liao \& Wu, 2009). Therefore, this research adopts KM -> OL effect which view $\mathrm{OL}$ is a reaction to $\mathrm{KM}$ at the Egyptian commercial banks. 


\subsection{The Relationship between $O L$ and $O P$}

De Geus (1988) argues that the ability to learn faster than your competitors may be the only sustainable competitive advantage and organizational superior performance.

OL can be defined as a continuous testing of experience and its transformation into knowledge available to whole organization and relevant to their mission (Senge, 1990). OL is a combination of four processes: information acquisition, information distribution, information interpretation and organizational memory (Huber, 1991).

$\mathrm{OL}$ is a process of information acquisition, information interpretation and resulting behavioural and cognitive changes, which should in turn have an impact on OP (Dimovski, 1994). OL is considered to be one of the most promising concepts in the modern managerial literature. The concept of OL is confused with the concepts of Learning Organization (LO). LO is considered as an entity-an ideal form of organization, which has the capacity to learn effectively and hence to prosper (Tsang, 1997).

OL tends to be positive, and descriptive, the idea of LO tends to be normative and prescriptive. It is necessary to hold on to the idea of the $\mathrm{LO}$ as a direction while the process of $\mathrm{OL}$ is seen as descriptive or heuristic device to explain and quantify learning activities and events (Jones \& Hendry, 1992). OL tends to focus more on internal concerns for performance and learning as part of condition of human beings within settings. OL tends to focus more on external threats as the reason for fostering learning (Kezar, 2005).

Many researchers consider OL as the fundamental aspect of competitiveness and link it with KM and OP. Jones (2000) emphasizes the importance of OL for OP defining it as a process through which managers try to increase organizational members' capabilities in order to understand better and manage an organization and its environment to accept decisions that increase OP on a continuous basis.

Škerlavaj \& Dimovski (2006) demonstrated the statistically significant positive impact of OL on OP from the employee perspective. Also, Škerlavaj et al (2007) established a statistically significant link between OL culture on OP, based on medium and large Slovenian companies.

The researches have long acknowledged the importance of OL to overall OP. An organization with a strong OL is not simply a collector or storehouse of knowledge but a processor of it (Liao \& Wu, 2009). This research investigates the influence of OL on OP. It attempts to determine which OP is the most and the least predictable when the effectiveness of OL is in the view, and even further, to identify how a presence of OL and quality of its' practice influence OP.

\subsection{The Relationship between KM and OP}

KM literature adopts a technical approach directed towards disseminating and leveraging knowledge in order to enhance OP (Škerlavaj \& Dimovski, 2006).

The roles of knowledge for OP have become clearer, that is, it must be organization result-driven (Gorelick \& Monsou, 2005; Wiig, 2002). Organizations need to assess and understand how KM best contributes to OP. Performance must be integrated with systematic and systematized learning to sustain competitive advantage and KM can be a vehicle for achieving this desired result (Gorelick \& Monsou, 2005). KM and OP are essential for the success in business. The different results in literatures that declare KM affects OP positively (Liao \& $\mathrm{Wu}$, 2009).

KM process affects OP positively. Knowledge acquisition doesn't positively affect OP directly, and knowledge dissemination doesn't positively affect OP (Darroch, 2005).

$\mathrm{KM}$ efforts were limited in their ability to yield significant OP. This limitation is further compounded by the fact that OP advantage is derived not from the knowledge resident in an organization but from how it is leveraged (Alavi \& Leidner, 2001). KM practices are positively associated with OP as generally suggested by the KM literature, both qualitative (Massey et al., 2002) and quantitative (Schulz \& Jobe, 2001; Choi \& Lee, 2003; Darroch \& McNaughton, 2003; Tanriverdi, 2005).

$\mathrm{KM}$ practices are related to various intermediate measures of strategic OP, and those intermediate measures are associated with financial performance. Based on this evidence, it was concluded that as long as KM practices enhance intermediate OP, positive financial performance will result (Lee \& Choi, 2003).

The practice of KM is that by locating and sharing useful knowledge, OP will improve (Davenport \& Prusak, 1998). One might expect KM to influence many different aspects of OP. KM has been linked positively to financial performance measures (Tanriverdi, 2005) and non-financial performance measures such as quality (Mukherjee et al., 1998). KM makes a difference to OP. Not only did KM practices have a direct relationship 
with intermediate measures of OP, but OP also exhibited a significant and direct relationship to financial performance. Also, there was no significant relationship between KM practices and financial performance (Zack, et al., 2009).

Effective KM through the development of capabilities should contribute to key aspects of OP. Also, when firms develop greater KM capabilities, they can more effectively develop marketing offerings to meet customer needs. With greater KM capabilities, firms can obtain and use knowledge more effectively and efficiently, which results in above-normal performance (Liao \& $\mathrm{Wu}, 2009$ ).

KM has been illustrated as a significant discipline in leading to positive performance in the organization. Without KM, the organization would not succeed in long-term survival and remain in competitive advantage. As an organization implements KM, its performance will be better, especially in a changing and unpredictable environment (Raja Suzana, 2004; 2005; 2008).

There has been a great deal of research explaining what makes KM the critical practices for OP (Gorelick \& Monsou, 2005; Liao \& Wu, 2009), but little research has been done on the association of KM to OP in the Arab environment. So, this study attempts to discover the relationship between KM and OP at the Egyptian commercial banks.

\section{Research Model}

There have been little empirical studies to demonstrate the relationship between KM and OP. Understanding this relationship is essential for managers if they hope to improve OP through KM (Asoh, 2003). There are studies focusing on the OP results of KM (Argote \& Ingram, 2000). The underlying assumption one might assume is that all new knowledge is good knowledge that automatically brings improved OP (Kalling, 2003).

Gold et al. (2001) and Mohrman, et al., (2003), suggested that OP is improved when the organization creates and uses knowledge. OP is improved through locating and sharing useful KM (Davenport \& Prusak, 1998). One might expect KM to influence many different aspects of OP. KM has been linked positively to OP (Tanriverdi, 2005; Francisco \& Guadamillas, 2002; Lapre \& Wassenhove, 2001).

Becerra-Fernandez, et al., (2004) discussed the impact of KM processes on people, processes, products and OP. KM could affect organizations in two main ways: (1) KM can help create knowledge, which can then contribute to improve OP; and (2) KM can directly cause improvements in people, processes, products and OP.

KM affects OL positively (Su, et al., 2004). KM had more indirect than direct influence on OP (Darroch, 2005).

OL has a significant impact on OP from the employee perspective (Škerlavaj \& Dimovski, 2006). KM and OL go hand in hand. It took several hundred years for the most advanced nation of the world that continue to challenge organizations to improve OP (Su et al., 2003; 2004; Ke \& Wei, 2006; Liao \& Wu, 2009). Salina \& Wan Fadzilah (2008) suggested that KM processes have a significant relationship with OP.

There is a lack of systematic study in the Egyptian context, especially public service sector. KM is still in its early stages and the contribution of KM is still a debatable issue. This research attempts to examine the relationship between $\mathrm{KM}, \mathrm{OL}$ and $\mathrm{OP}$.

From the above discussion, the researcher noticed that KM contributes significantly to OP, and the existence of OL helps improve OP. In another words, organizations which develop their learning processes congruently will increase their performance. However, if OL fully mediates the relationship between KM and OP, it shows that the relationship between KM and OP is insignificant with the presence of OL. The research model is as shown in Figure 1 below. 


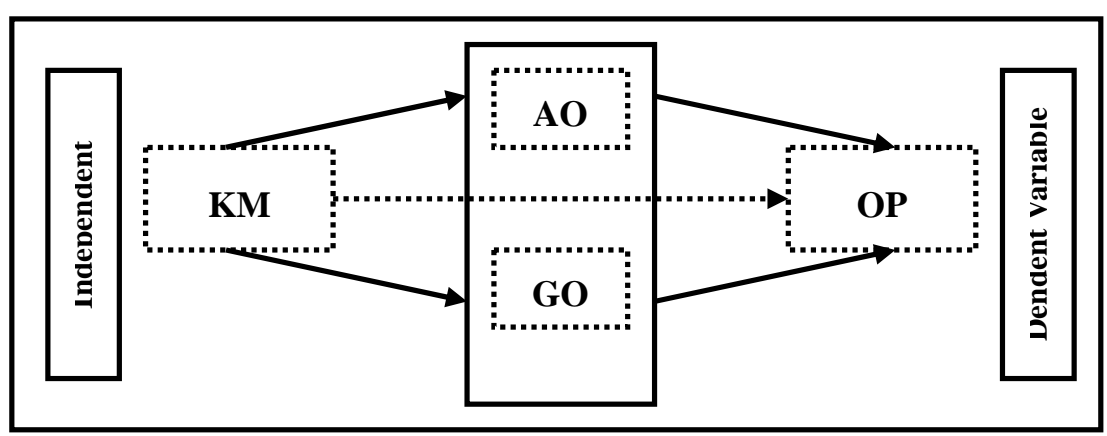

Figure 1. The Framework of the relationship among the variables

\section{Research Questions and Hypotheses}

Q1: What is the relationship between $\mathrm{KM}$ and $\mathrm{OL}$ at the Egyptian commercial banks?

Q2: What is the impact of OL on OP at the Egyptian commercial banks?

Q3: Is there a relationship between KM and OP at the Egyptian commercial banks?

This study attempts to test the following hypotheses:

$\mathrm{H} 1$ : There is no relationship between KM and OL at the Egyptian commercial banks.

$\mathrm{H} 2$ : There is no impact of OL on OP at the Egyptian commercial banks.

H3: There is no relationship between KM and OP at the Egyptian commercial banks.

\section{Research Methods}

\subsection{Population and Sample}

In this study population was all employees at the Egyptian commercial banks. The total population is 66.536 employees. The stratified random sample was used while selecting items from the different employees. Determination of respondent sample size was calculated using the formula (Daniel, 1999) as follows:

$$
N=\frac{N \times(z)^{2} \times P(1-P)}{d^{2}(N-1)+(Z)^{2} \times P(1-P)}
$$

So the number of samples obtained by 382 employees as presented in Table 1.

Table 1. Distribution of the sample size

\begin{tabular}{|c|c|c|c|}
\hline Bank Type & $\begin{array}{l}\text { Number of } \\
\text { Population }\end{array}$ & Percentage & Sample Size \\
\hline General Commercial Banks & 52564 & $79 \%$ & $382 \times 79 \%=302$ \\
\hline joint Commercial Banks & 11977 & $18 \%$ & $382 \times 18 \%=69$ \\
\hline Foreign Branches of Banks & 1995 & $3 \%$ & $382 \times 3 \%=11$ \\
\hline Total & 66536 & $100 \%$ & $382 \times 100 \%=382$ \\
\hline
\end{tabular}

Source: Egyptian Central Bank, Economic Magazine, 2012. 
Table 2. Characteristics of the sample units

\begin{tabular}{|c|c|c|c|}
\hline Variables & & Number & Percentage \\
\hline \multirow{9}{*}{ 1- Job Title } & General Manager & 17 & $\% 9$ \\
\hline & Deputy General Manager & 20 & $\% 16$ \\
\hline & Agent General Manager & 20 & $\% 26$ \\
\hline & Deputy Manager & 28 & $\% 16$ \\
\hline & Controller & 35 & $\% 33$ \\
\hline & Excellent Banker & 43 & $\% 26$ \\
\hline & Banker A & 37 & $\% 16$ \\
\hline & Banker B & 85 & $\% 33$ \\
\hline & Total & 285 & $\% 100$ \\
\hline \multirow{3}{*}{ 2- Marital Status } & Married & 223 & $\% 72$ \\
\hline & Single & 87 & $\% 28$ \\
\hline & Total & 223 & $\% 100$ \\
\hline \multirow{4}{*}{ 3- Age } & Less than 30 years & 124 & $\% 40$ \\
\hline & From 30 to 45 & 160 & $\% 52$ \\
\hline & More than 45 & 26 & $\% 8$ \\
\hline & Total & 310 & $\% 100$ \\
\hline \multirow{3}{*}{ 4- Educational Level } & University Education & 136 & $\% 44$ \\
\hline & Post Graduate Studies & 174 & $\% 56$ \\
\hline & Total & 310 & $\% 100$ \\
\hline \multirow{4}{*}{ 5- Period of Experience } & Less than 5 years & 62 & $\% 20$ \\
\hline & From 5 to 10 & 221 & $\% 71$ \\
\hline & More than 10 & 27 & $\% 9$ \\
\hline & Total & 310 & $\% 100$ \\
\hline
\end{tabular}

\subsection{Method of Data Collection}

A survey-based descriptive research design is used. The study was carried out at Egyptian commercial banks. The questionnaire included four questions, relating to recognizing KM, OL, OP and biographical information of employees at Egyptian commercial banks.

Few employees completed 25 questionnaires but some changes took place. The questionnaires were completed anonymously during group administration. Data collection took approximately two months. About 382 survey questionnaires were distributed by employing diverse modes of communication such as in person and post. Multiple follow-ups yielded 310 statistically usable questionnaires. Survey responses were $81 \%$.

\subsection{Research Variables and Methods of Measuring}

This research studied the relationship between KM, OL, and OP from the point of employees at the Egyptian Commercial Banks. In referencing exiting literature, the study established a basic research model. Figure 1 shows that KM is independent variable; OP is the dependent variable; OL is the mediator variable. The study of data collected through questionnaires with four: KM, OL, OP, and basic respondent demographic data.

The survey uses the fifth - point Likert scale. The 25-item scale KM is based on Jakob, 2003; and Wiig, 2003. The 14- item scale OL is based on Senge et al., 1994; Voci \& Young, 2001; Smith \& Taylor, 2000; Appeldan \& Goramsson 1997; and Osterberg, 2004. The 7-item scale OP is based on Darroch, 2003; Pathirage, et al., 2007; Chen \& Mohamed, 2007; and Lurdvall \& Nielsen, 2007.

\subsection{Methods of Data Analysis and Testing Hypotheses}

The researcher has employed the following methods: (1) Cronbach's alpha, (2) Multiple Regression Analysis (MRA), and (3) F- test and T-test. All these tests are found in SPSS.

\section{Hypotheses Testing}

\subsection{Evaluating Reliability}

Data analysis was conducted in there major phases. All scales were first subjected to reliability analysis. Cronbach's alpha was used to assess the internal consistency reliability of the scales. Item analysis indicated that dropping any items from the scales would not significantly raise the alphas. Table (3) presents the reliability of $\mathrm{KM}, \mathrm{OL}$, and $\mathrm{OP}$ at the Egyptian commercial banks. 
Table 3. Reliability of KM, OL, OP

\begin{tabular}{llll}
\hline \multirow{2}{*}{ Variables } & The Dimensions & Number & of \\
& Statement & ACC \\
\hline \multirow{2}{*}{ KM } & Knowledge Creation & 5 & 0.7398 \\
& Knowledge Acquisition & 5 & 0.7719 \\
& Knowledge Organization & 5 & 0.6677 \\
& Knowledge Distribution & 5 & 0.6709 \\
& Use of Knowledge & 5 & 0.6382 \\
OL & Total Measurement & $\mathbf{0 . 9 2 5 0}$ \\
& Adaptive Organizational Learning & $\mathbf{2 5}$ & 0.9341 \\
& Generative Organizational Learning & 7 & 0.9159 \\
OP & Total Measurement & 7 & $\mathbf{0 . 9 6 0 2}$ \\
& Comparative Performance & $\mathbf{1 4}$ & 0.8799 \\
& Internal Performance & 3 & 0.8260 \\
\end{tabular}

According Table 3, the overall reliability of $\mathrm{KM}$ is 0.92 . The overall reliability of $\mathrm{OL}$ is 0.96 . The overall reliability of OP is 0.92 . All the measures of these scales were sufficiently reliable.

6.2 The Relationship between KM and $O L$

The relationship between KM and OL are studied. The first hypothesis to be tested is:

H1: There is no statistically significant relationship between KM and OL at the Egyptian commercial banks.

Table 4. Correlation coefficients between KM and OL

\begin{tabular}{llll}
\hline The Dimension of KM & $\begin{array}{l}\text { The Dimension of OL } \\
\text { AOL }\end{array}$ & GOL & $\begin{array}{l}\text { Total } \\
\text { OL }\end{array}$ \\
\hline Knowledge Creation & $0.489^{* *}$ & $0.526^{* *}$ & $0.519^{* *}$ \\
Knowledge Acquisition & $0.459^{* *}$ & $0.499^{* *}$ & $0.490^{* *}$ \\
Knowledge Organization & $0.389^{* *}$ & $0.430^{* *}$ & $0.418^{* *}$ \\
Knowledge Distribution & $0.400^{* *}$ & $0.439^{* *}$ & $0.429^{* *}$ \\
Use of Knowledge & $0.458^{* *}$ & $0.481^{* *}$ & $0.428^{* *}$ \\
Total Measurement & $\mathbf{0 . 4 9 4 ^ { * * }}$ & $\mathbf{0 . 5 3 4}^{* *}$ & $\mathbf{0 . 5 2 6}$ \\
\hline
\end{tabular}

According to Table 4, there is a significant correlation between KM and OL. The following section will discuss the relationship between the aspects of KM and OL.

6.2.1 The Relationship between KM (Knowledge Creation) and OL

Table 5. The relationship between knowledge creation and OL

\begin{tabular}{|c|c|c|c|}
\hline The Variables of Knowledge Creation & Beta & $\mathrm{R}$ & $\mathrm{R}^{2}$ \\
\hline The bank identifies information needs to be able to provide them. & $0.197^{* *}$ & 0.280 & 0.078 \\
\hline $\begin{array}{l}\text { The bank employs scientific research in the provision of knowledge related to its } \\
\text { objectives. }\end{array}$ & 0.012 & 0.372 & 0.138 \\
\hline Views and experiences are recorded and saved in the database. & $0.258^{* *}$ & 0.383 & 0.146 \\
\hline The bank's seeking to provide data to fill the knowledge gap. & $0.410^{* *}$ & 0.515 & 0.265 \\
\hline The availability of bank data helps employees to solve problems that face them. & 0.053 & 0.289 & 0.083 \\
\hline
\end{tabular}




\begin{tabular}{cll}
\hline - & Multiple Correlation Coefficients & 0.588 \\
- & Coefficient of Determination & 0.346 \\
- & The Value of Calculated F & 32.127 \\
- & Degree of Freedom & 5,304 \\
- & Leve Value of Indexed F & 3.01 \\
\hline$* 0.01$. & & 0.01 \\
\hline
\end{tabular}

According to the results of MRA, there is a relationship between knowledge creation and OL in significance level of 0,000 . Moreover, the value of $\mathrm{R}^{2}$, knowledge creation can explain $34 \%$ of the total differentiation in OL level.

For the results of a structural analysis of the MRA, the direct effect of knowledge creation and OL is obtained. Because MCC is 0.59, then it is concluded that there is enough empirical evidence to reject the null hypothesis.

6.2.2 The Relationship between KM (Knowledge Acquisition) and OL

Table 6. The relationship between knowledge acquisition and OL

\begin{tabular}{llll}
\hline The Variables of Knowledge Acquisition & Beta & $\mathrm{R}$ & $\mathrm{R}^{2}$ \\
\hline The bank gains knowledge from similar banks. & $0.392^{* *}$ & 0.502 & 0.252 \\
The bank gains knowledge through consultants in scientific institutes. & $0.170^{*}$ & 0.349 & 0.121 \\
The bank tries to acquire knowledge through banks around. & 0.034 & 0.367 & 0.134 \\
The bank helps employees acquire knowledge in different fields. & 0.067 & 0.260 & 0.067 \\
The employees acquire knowledge through libraries and the Internet. & $0.231^{* *}$ & 0.313 & 0.097 \\
\hline - Multiple Correlation Coefficients & 0.569 & \\
- Toefficient of Determination & 0.323 & \\
- De Value of Calculated F & 29.059 & \\
- The Value of Indexed F & 5,304 & \\
\hline$\quad$ Level of Significant & 3.01 & \\
\hline
\end{tabular}

Regarding to the results of MRA, there is a relationship between knowledge acquisition and OL in significance level of 0,000 . As a result of the value of $\mathrm{R}^{2}$, knowledge acquisition can explain $32 \%$ of the total differentiation in OL level.

The results of a structural analysis of the MRA model directly influence knowledge acquisition variable toward OL. Because MCC is 0.56, then there is enough empirical evidence to reject the null hypothesis.

6.2.3 The Relationship between KM (Knowledge Organization) and OL

Table 7. The relationship between knowledge organization and $\mathrm{OL}$

\begin{tabular}{llll}
\hline The Variables of Knowledge Organization & Beta & $\mathrm{R}$ & $\mathrm{R}^{2}$ \\
\hline The bank selects modern methods of organizing knowledge. & $0.250^{* *}$ & 0.241 & 0.058 \\
The bank classifies the data to take advantage of them. & 0.020 & 0.253 & 0.064 \\
The bank classifies primary data and converts them to information. & $0.134^{*}$ & 0.263 & 0.069 \\
The bank has a database for the classification of knowledge. & 0.082 & 0.204 & 0.041 \\
The bank specifies all what is new for the organization and classification of knowledge. & $0.419^{* *}$ & 0.418 & 0.174 \\
\hline - Multiple Correlation Coefficients & 0.509 & \\
- $\quad$ Coefficient of Determination & 0.259 & \\
- The Value of Calculated F & 21.254 & \\
- Degree of Freedom & 5,304 & \\
- The Value of Indexed F & 3.01 & \\
\hline
\end{tabular}

$* \mathrm{P}<.05 ; * * \mathrm{P}<.01$. 
Concerning the results of MRA, there is a relationship between knowledge organization and OL in significance level of 0,000 . As a result of the value of $\mathrm{R}^{2}$, knowledge organization can explain $25 \%$ of the total differentiation in OL level.

According to the results of MRA, the there is a fundamental relationship between knowledge organization and OL. Because MCC is 0.51, then it is concluded that there is evidence to reject the null hypothesis.

6.2.4 The Relationship between KM (Knowledge Distribution) and OL

Table 8. The relationship between knowledge distribution and OL

\begin{tabular}{llll}
\hline The Variables of Knowledge Distribution & Beta & $\mathrm{R}$ & $\mathrm{R}^{2}$ \\
\hline The bank distributes knowledge through e-mail. & $0.124^{*}$ & 0.263 & 0.069 \\
The bank wishes to issue bulletins for the knowledge distribution. & $0.253^{* *}$ & 0.247 & 0.061 \\
There is a bank system that contributes to the distribution of knowledge on the right time & 0.055 & 0.220 & 0.048 \\
The bank uses the meetings as a means to distribute knowledge. & 0.015 & 0.262 & 0.068 \\
The bank holds training courses on how to use knowledge. & $0.415^{* *}$ & 0.424 & 0.179 \\
\hline - $\quad$ Multiple Correlation Coefficients & 0.513 & \\
- $\quad$ Coefficient of Determination & 0.263 & \\
- The Value of Calculated F & 21.663 & \\
- Degree of Freedom & 5,304 & \\
- The Value of Indexed F & 3.01 & \\
- Level of Significant & 0.01 & \\
\hline
\end{tabular}

$* \mathrm{P}<.05 ; * * \mathrm{P}<.01$.

According to the results of MRA, there is a relationship between knowledge distribution and OL in significance level of 0,000 . As a result of the value of $\mathrm{R}^{2}$, knowledge distribution can explain $26 \%$ of the total differentiation in OL level.

For the results of a structural analysis of the MRA model, the direct effect of knowledge distribution and OL is obtained. Because MCC is 0.51, then it is concluded that there is enough empirical evidence to reject the null hypothesis.

6.2.5 The Relationship between KM (Use of knowledge) and OL

Table 9. The Relationship between the use of knowledge and OL

\begin{tabular}{|c|c|c|c|}
\hline The Variables of Use of Knowledge & Beta & $\mathrm{R}$ & $\mathrm{R}^{2}$ \\
\hline The bank uses the knowledge among employees in the same administrative level bank. & $0.158^{* *}$ & 0.280 & 0.078 \\
\hline $\begin{array}{l}\text { Knowledge is traded among workers in the different administrative levels within the } \\
\text { bank. }\end{array}$ & $0.433^{* *}$ & 0.502 & 0.252 \\
\hline The use of knowledge increases the functional skill of employees & $0.153^{* *}$ & 0.241 & 0.058 \\
\hline $\begin{array}{l}\text { The use of knowledge helps employees to raise the level of service provided to the } \\
\text { customers }\end{array}$ & 0.073 & 0.263 & 0.069 \\
\hline The use of knowledge helps staff creativity and development & $0.158^{* *}$ & 0.280 & 0.078 \\
\hline - $\quad$ Multiple Correlation Coefficients & 0.564 & & \\
\hline - Coefficient of Determination & 0.318 & & \\
\hline The Value of Calculated F & 35.542 & & \\
\hline - $\quad$ Degree of Freedom & 5,304 & & \\
\hline - $\quad$ The Value of Indexed F & 3.01 & & \\
\hline Level of Significant & 0.01 & & \\
\hline
\end{tabular}

Regarding to the results of MRA, there is a relationship between the use of knowledge and OL in significance level of 0,000 . As a result of the value of $\mathrm{R}^{2}$, the use of knowledge can explain $31 \%$ of the total differentiation in OL level. 
The results of a structural analysis of the MRA model directly influence the use of knowledge variable toward OL. Because MCC is 0.56, then there is enough empirical evidence to reject the null hypothesis.

\subsection{The Relationship between $O L$ and $O P$}

The relationship between KM and OL is determined. The second hypothesis to be tested is:

H2: There is no statistically significant relationship between $\mathrm{OL}$ and $\mathrm{OP}$ at the Egyptian commercial banks.

Table 10. Correlation coefficients between OL and OP

\begin{tabular}{llll}
\hline & \multicolumn{2}{c}{ The Dimension of OP } & Total \\
The Dimension of OL & $\begin{array}{l}\text { Comparative } \\
\text { Performance }\end{array}$ & $\begin{array}{l}\text { Internal } \\
\text { Performance }\end{array}$ & OP \\
\hline Adaptive Organizational Learning & $0.888^{* *}$ & $0.884^{* *}$ & $0.907^{* *}$ \\
Generative Organizational Learning & $0.897^{* *}$ & $0.913^{* *}$ & $0.927^{* *}$ \\
Total Measurement & $\mathbf{0 . 9 1 3}^{* *}$ & $\mathbf{0 . 9 2 0}^{* *}$ & $\mathbf{0 . 9 3 8}^{* *}$ \\
\hline
\end{tabular}

According to Table 10, there is significant correlation between the aspects of OL and OP. The following section will discuss the relationship between the aspects of OL and OP.

6.3.1 The Relationship between OL (AOL) and OP

Table 11. The relationship between AOL and OP

\begin{tabular}{|c|c|c|c|}
\hline The Variables of AOL & Beta & $\mathrm{R}$ & $\mathrm{R}^{2}$ \\
\hline $\begin{array}{l}\text { The bank administration recognizes that training and development are fundamental } \\
\text { functions. }\end{array}$ & $0.151^{* *}$ & 0.804 & 0.646 \\
\hline $\begin{array}{l}\text { Bank administration is trying to deal with anything that happens in the external } \\
\text { environment. }\end{array}$ & 0.056 & 0.824 & 0.678 \\
\hline The bank is ready to learn from other banks on how to develop methods to work with. & $0.343^{* *}$ & 0.856 & 0.732 \\
\hline $\begin{array}{l}\text { If an error occurs in my bank, I expect the assistance and support from others to learn } \\
\text { from this error. }\end{array}$ & 0.045 & 0.797 & 0.635 \\
\hline $\begin{array}{l}\text { The bank sets up training programs for workers at all stages of the development of their } \\
\text { professional work. }\end{array}$ & 0.005 & 0.662 & 0.438 \\
\hline $\begin{array}{l}\text { The bank administration is aware that the certificate obtained by the individual is an } \\
\text { important part that must be completed through the applied knowledge acquired through } \\
\text { his work. }\end{array}$ & $0.486^{* *}$ & 0.849 & 0.720 \\
\hline $\begin{array}{l}\text { I need to learn new knowledge and techniques so that I can complete my work at the } \\
\text { bank. }\end{array}$ & $0.093^{* *}$ & 0.615 & $0 . .378$ \\
\hline - $\quad$ Multiple Correlation Coefficients & 0.937 & & \\
\hline - Coefficient of Determination & 0.877 & & \\
\hline - $\quad$ The Value of Calculated F & 308.939 & & \\
\hline - Degree of Freedom & 7,302 & & \\
\hline - $\quad$ The Value of Indexed F & 2.63 & & \\
\hline - $\quad$ Level of Significant & 0.01 & & \\
\hline
\end{tabular}

Concerning the results of MRA, there is a relationship between AOL and OP in significance level of 0,000 . As a result of the value of $\mathrm{R}^{2}$, AOL can explain $87 \%$ of the total differentiation in OP level.

For the results of a structural analysis of the MRA model, the direct effect of AOL and OL is obtained. Because MCC is 0.93, then it is concluded that there is enough empirical evidence to reject the null hypothesis.

6.3.2 The Relationship between OL (GOL) and OP 
Table 12. The relationship between GOL and OP

\begin{tabular}{|c|c|c|c|}
\hline The Variables of GOL & Beta & $\mathrm{R}$ & $\mathrm{R}^{2}$ \\
\hline The bank administration is open to ideas and proposals of employees. & $0.032^{*}$ & 0.541 & 0.292 \\
\hline $\begin{array}{l}\text { Bank staff is always in a position to encourage reflection on the submission of proposals } \\
\text { that would improve its working methods. }\end{array}$ & $0.474^{* *}$ & 0.918 & 0.842 \\
\hline Bank staff has adequate time to learn from problems rather than solve only. & $0.197^{* *}$ & 0.801 & 0.641 \\
\hline $\begin{array}{l}\text { It is important for bank staff to have the opportunity for experimentation and the search for } \\
\text { better ways to accomplish the work. }\end{array}$ & $0.084^{* *}$ & 0.869 & 0.755 \\
\hline There is openness between bank staff regarding the exchange of different viewpoints. & 0.019 & 0.553 & 0.305 \\
\hline The administration of the bank continues to exchange views with the staff. & $0.389^{* *}$ & 0.852 & 0.725 \\
\hline Debate among the bank staff focuses on ideas not on persons who say these ideas. & $0.028^{* *}$ & 0.793 & 0.628 \\
\hline - $\quad$ Multiple Correlation Coefficients & 0.974 & & \\
\hline - Coefficient of Determination & 0.948 & & \\
\hline The Value of Calculated F & 786.440 & & \\
\hline - $\quad$ Degree of Freedom & 7,302 & & \\
\hline - $\quad$ The Value of Indexed F & 2.63 & & \\
\hline Level of Significant $t$ & 0.01 & & \\
\hline
\end{tabular}

According to the results of MRA, there is a relationship between GOL and OP in significance level of 0,000 . As a result of the value of $\mathrm{R}^{2}$, GOL can explain $94 \%$ of the total differentiation in OP level.

The results of a structural analysis of the MRA model directly influence the GOL toward OL. Because MCC is 0.97, then there is enough empirical evidence to reject the null hypothesis at the statistical significance level of 0.01 .

6.4 The Relationship between KM and $\mathrm{OP}$

The statistical results for the relationship between KM and OL are investigated. The third hypothesis to be tested is:

H3: There is no statistically significant relationship between KM and OP at the Egyptian commercial banks.

Table 13. Correlation coefficients between KM and OP

\begin{tabular}{llll}
\hline The Dimension of KM & $\begin{array}{l}\text { The Dimension of OP } \\
\text { Comparative } \\
\text { Performance }\end{array}$ & Internal Performance & $\begin{array}{l}\text { Total } \\
\text { OP }\end{array}$ \\
\hline Knowledge Creation & $0.442^{* *}$ & $0.468^{* *}$ & $0.466^{* *}$ \\
Knowledge Acquisition & $0.405^{* *}$ & $0.435^{* *}$ & $0.431^{* *}$ \\
Knowledge Organization & $0.326^{* *}$ & $0.359^{* *}$ & $0.351^{* *}$ \\
Knowledge Distribution & $0.340^{* *}$ & $0.372^{* *}$ & $0.365^{* *}$ \\
Use of Knowledge & $0.403^{* *}$ & $0.390^{* *}$ & $0.405^{* *}$ \\
\hline Total Measurement & $\mathbf{0 . 4 3 1 * *}^{* * 4}$ & $\mathbf{0 . 4 5 5}^{* *}$ & $\mathbf{0 . 4 5 4}^{* *}$ \\
\hline
\end{tabular}

According to Table (13), there is a significant correlation between KM and OP. The following section will discuss the relationship between the aspects of KM and OP.

6.4.1 The Relationship between KM (Knowledge Creation) and OP 
Table 14. The relationship between Knowledge Creation and OP

\begin{tabular}{llll}
\hline The Variables of Knowledge Creation & Beta & $\mathrm{R}$ & $\mathrm{R}^{2}$ \\
\hline The bank identifies information needs to be able to provide them. & $0.158^{*}$ & 0.229 & 0.052 \\
The bank employs scientific research in the provision of knowledge related to its & 0.053 & 0.326 & 0.0 .106 \\
objectives. & $0.321^{*}$ & 0.382 & 0.145 \\
Views and experiences are recorded and saved in the database. & $0.399^{*}$ & 0.477 & 0.227 \\
The bank's seeking to provide data to fill the knowledge gap. & 0.106 & 0.239 & 0.057 \\
The availability of bank data helps employees solve problems that face them. & 0.553 & & \\
\hline - Multiple Correlation Coefficients $\quad$ Coefficient of Determination & 0.306 & & \\
- The Value of Calculated F & 26.854 & & \\
- Degree of Freedom & 5,304 & & \\
- The Value of Indexed F & 3.01 & & \\
- Level of Significant & 0.01 & &
\end{tabular}

$* \mathrm{P}<.05 ; * * \mathrm{P}<.01$.

According to the results of MRA, there is a relationship between knowledge creation and OP in significance level of 0,000 . As a result of the value of $\mathrm{R}^{2}$, knowledge creation can explain $31 \%$ of the total differentiation in OP level.

For the results of a structural analysis of the MRA model, the direct effect of knowledge creation and OP is obtained. Because MCC is 0.55 , then it is concluded that there is enough empirical evidence to reject the null hypothesis.

6.4.2 The Relationship between KM (Knowledge Acquisition) and OP

Table 15. The relationship between knowledge acquisition and OP

\begin{tabular}{llll}
\hline The Variables of Knowledge Acquisition & Beta & $\mathrm{R}$ & $\mathrm{R}^{2}$ \\
\hline The bank gains knowledge from similar banks. & $0.372^{* *}$ & 0.460 & 0.211 \\
The bank gains knowledge through consultants in universities and scientific institutes. & $0.186^{* *}$ & 0.316 & 0.099 \\
The bank tries to acquire knowledge through banks around. & $0.027^{* *}$ & 0.325 & 0.105 \\
The bank helps employees acquire knowledge in different fields. & 0.114 & 0.208 & 0.043 \\
The employees in the bank acquire knowledge through libraries and the internet. & $0.195^{* *}$ & 0.268 & 0.071 \\
\hline - $\quad$ Multiple Correlation Coefficients & 0.517 & \\
- $\quad$ Coefficient of Determination & 0.267 & \\
- The Value of Calculated F & 22.182 & \\
- Degree of Freedom & 5,304 & \\
- The Value of Indexed F & 3.01 & \\
- $\quad$ Level of Significant & 0.01 & & \\
\hline$* 01 \quad \mathrm{P}<01$ & &
\end{tabular}

Regarding to the results of MRA, there is a relationship between knowledge acquisition and OP in significance level of 0,000 . The value of $\mathrm{R}^{2}$, knowledge acquisition can explain $26 \%$ of the total differentiation in OP level.

The results of a structural analysis of the MRA model directly influence knowledge acquisition variable toward OP. Because MCC is 0.51, then there is enough empirical evidence to reject the null hypothesis. 


\subsubsection{The Relationship between KM (Knowledge Organization) and OP}

Table 16. The relationship between knowledge organization and OP

\begin{tabular}{llll}
\hline The Variables of Knowledge Organization & Beta & $\mathrm{R}$ & $\mathrm{R}^{2}$ \\
\hline The bank selects modern methods of organizing knowledge. & $0.197^{* *}$ & 0.187 & 0.034 \\
The bank classifies the data and information in a scientific way to take advantage of them. & 0.002 & 0.208 & 0.043 \\
The bank classifies primary data and then converts them to information. & 0.112 & 0.224 & 0.050 \\
The bank has a database for the classification of knowledge. & 0.039 & 0.188 & 0.035 \\
The bank specifies all what is new for the organization and classification of knowledge. & $0.345^{* *}$ & 0.353 & 0.124 \\
\hline - $\quad$ Multiple Correlation Coefficients & 0.420 & \\
- Coefficient of Determination & 0.176 & \\
- The Value of Calculated F & 13.015 & \\
- Degree of Freedom & 5,304 & \\
- The Value of Indexed F & 3.01 & \\
\hline
\end{tabular}

$* * \mathrm{P}<.01$.

Concerning the results of MRA, there is a relationship between knowledge organization and OP in significance level of 0,000 . The value of $\mathrm{R}^{2}$, knowledge organization can explain $26 \%$ of the total differentiation in OP level.

For the results of a structural analysis of the MRA model, the direct effect of knowledge organization and OP is obtained. Because MCC is 0.42, then it is concluded that there is enough empirical evidence to reject the null hypothesis.

6.4.4 The Relationship between KM (Knowledge Distribution) and OP

Table 17. The relationship between knowledge distribution and OP

\begin{tabular}{llll}
\hline The Variables of Knowledge Distribution & Beta & $\mathrm{R}$ & $\mathrm{R}^{2}$ \\
\hline The bank distributes knowledge through e-mail. & 0.099 & 0.224 & 0.050 \\
The bank wishes to issue bulletins for the knowledge distribution. & $0.200^{* *}$ & 0.192 & 0.036 \\
There is a bank system that contributes to the distribution of knowledge on the right time. & 0.008 & 0.209 & 0.043 \\
The bank uses the meetings as a means to distribute knowledge. & 0.004 & 0.219 & 0.047 \\
The bank holds training courses on how to use knowledge. & $0.345^{* *}$ & 0.363 & 0.131 \\
\hline - $\quad$ Multiple Correlation Coefficients & 0.428 & \\
- $\quad$ Coefficient of Determination & 0.183 & \\
- $\quad$ The Value of Calculated F & 13.625 & \\
- $\quad$ Degree of Freedom & 5,304 & \\
- $\quad$ The Value of Indexed F & 3.01 & \\
- $\quad$ Level of Significant & 0.01 & \\
\hline
\end{tabular}

According to the results of MRA, there is a relationship between knowledge distribution and OP in significance level of 0,000 . As a result of the value of $\mathrm{R}^{2}$, knowledge distribution can explain $18 \%$ of the total differentiation in OP level.

The results of a structural analysis of the MRA model directly influence knowledge distribution variable toward OP. Because MCC is 0.42, then there is enough empirical evidence to reject the null hypothesis. 
6.4.5 The Relationship between KM (Use of knowledge) and OP

Table 18. The relationship between the use of knowledge and OP

\begin{tabular}{llll}
\hline The Variables of Use of Knowledge & Beta & $\mathrm{R}$ & $\mathrm{R}^{2}$ \\
\hline The bank uses the knowledge among employees in the same administrative level bank & $0.125^{*}$ & 0.229 & 0.052 \\
Knowledge is traded among workers in the different administrative levels within the bank & $0.410^{* *}$ & 0.460 & 0.211 \\
The use of knowledge increases the functional skill of employees & $0.111^{*}$ & 0.181 & 0.032 \\
The use of knowledge helps employees to raise the level of service provided to the & 0.050 & 0.224 & 0.050 \\
customers & $0.125^{*}$ & 0.229 & 0.052 \\
The use of knowledge helps staff creativity and development & 0.499 & \\
\hline - $\quad$ Multiple Correlation Coefficients & 0.249 & \\
- $\quad$ Coefficient of Determination & 25,264 & \\
- $\quad$ Degree Value of Calculated F & 5,304 & \\
- $\quad$ The Value of Indexed F & 3.01 & \\
- $\quad$ Level of Significant & 0.01 &
\end{tabular}

Regarding to the results of MRA, there is a relationship between the use of knowledge and OP in significance level of 0,000 . As a result of the value of $\mathrm{R}^{2}$, the use of knowledge can explain $24 \%$ of the total differentiation in OP level.

For the results of a structural analysis of the MRA model, the direct effect of the use of knowledge and OP is obtained. Because MCC is 0.49 , then it is concluded that there is enough empirical evidence to reject the null hypothesis.

\section{Research Findings}

1) The results showed that KM affects OL. The results are consistent with research conducted by DeGeus, 1988; Senge, 1990; Liao \& Wu, 2009; Nonaka \& Takeuchi, 1995; Su, et al., 2003; Garratt, 1990, Su, et al., 2004; Su, et al., 2004; Darroch, 2005; Ke \& Wei, 2006; Liao \& Wu, 2009.

2) The results showed that OL affects OP. The results are consistent with research conducted by De Geus, 1988; Senge, 1990; Huber, 1991; Dimovski, 1994; Tsang, 1997; Jones \& Hendry, 1992; Kezar, 2005; Jones, 2000; Škerlavaj \& Dimovski, 2006; Škerlavaj et al., 2007; Liao \& Wu, 2009.

3) The results showed that KM affects OP. The results are consistent with research conducted by Škerlavaj \& Dimovski, 2006; Wiig, 2002; Gorelick \& Monsou, 2005; Liao \& Wu, 2009; Darroch, 2005; Alavi \& Leidner, 2001; Massey et al., 2002; Schulz \& Jobe, 2001; Choi \& Lee, 2003; Darroch \& McNaughton, 2003; Tanriverdi, 2005; Lee \& Choi, 2003; Davenport \& Prusak, 1998; Zack, et al., 2009; Mukherjee et al., 1998; Liao \& Wu, 2009; Raja Suzana, 2004; 2005; 2008; Gorelick \& Monsou, 2005; Liao \& Wu, 2009.

\section{Recommendations}

Understanding the relationships among KM, OL, and OP is essential for managers if they hope to improve OP through KM. Therefore, the manager needs to take the following factors into account:

1) The managers at the Egyptian banks need to acquire more knowledge to generate greater OP because it is confirmed that knowledge creation, acquisition, organization, distribution and use of knowledge are the main contributors to better performance.

2) The managers at the Egyptian banks also need to acknowledge the importance of OL, which is observed to act as mediator between KM processes and OP in this study. In other words, although KM processes contribute significantly to OP, the existence of OL helps improve OP. However, if OL fully mediates the relationship between KM processes and OP, it shows that the relationship between KM processes and OP is insignificant with the presence of OL.

3) The researcher hopes and believes that the model developed and tested presents relatively well balanced relationship between complexity of OL process and OP in modern business environment, and simplicity of its formulation in the model. 
4) The importance of systematic efforts to achieve strategic, generative or double-loop OL for strategic management of modern companies in their perpetual quest for competitive advantage is demonstrated.

5) The researcher hopes to clarify the important relationship among the variables leading to more comprehensive investigations.

6) The implication of the evolution of KM just described is clear. KM and OL should join forces and develop a unified discipline. KM needs OL and its expanding body of good research work. OL needs the practitioner base of KM and its abiding interest in problems and practice. Indeed, members of the KM and OL disciplines ought to be more actively involved in monitoring and evaluating each other's promising new theories and practices

7) Public service managers have many roles and responsibilities at the Egyptian banks, such as managing learning. Top management needs to have specific competencies knowledge, and ability to create and enhance the learning atmosphere in the organization. Also, top management need to understand and identify what factors contribute to the effectiveness of $\mathrm{OP}$ and what factors hinder such processes among the public service managers. In addition, top management need to promote the creation of intelligent organizations where people develop personally and professionally.

\section{References}

Akroush, M., \& Al-Mohammad, S. (2010). The Effect of Marketing Knowledge Management on Organizational Performance: An Empirical Investigation of the Telecommunications Organizations in Jordan. International Journal of Emerging Markets, 5(1), 38-77. http://dx.doi.org/10.1108/17468801011018266

Alavi, M., \& Leidner, E. (2001). Knowledge Management and Knowledge Management Systems: Conceptual Foundations and Research Issues. MIS Quarterly, 25(1), 107-136. http://dx.doi.org/10.2307/3250961

Anand, A., \& Singh, M. (2011). Understanding Knowledge Management: A Literature Review. International Journal of Engineering Science and Technology, 3(2), 926-939.

Anantatmula, V. (2007). Linking Knowledge Management Effectiveness Attributes to Organizational Performance.

Argote, L., \& Ingram, P. (2000). Knowledge Transfer: A Basis for Competitive Advantage in Firms. Organizational Behavior and Human Decision Processes, 82(1), 150-169. http://dx.doi.org/10.1006/obhd.2000.2893

Asoh, D. (2003). The Impact of Knowledge Management Strategies on Organizational Performance. Paper Presented to The Forth European Conference on Organizational Knowledge, Learning and Capabilities, Barcelona, Spain.

Becerra-Fernandez, I., Gonzalez, A., \& Sabherwal, R. (2004). Knowledge Management: Challenges, Solutions and Technologies. New Jersey, Pearson Education Incorporation.

Chen, C., \& Huang, J. (2007). How Organizational Climate and Structure Affect Knowledge Management. International Journal of Information Management, 27, 104-118. http://dx.doi.org/10.1016/j.ijinfomgt.2006.11.001

Choi, B., \& Lee, B. (2003). An Empirical Investigation of KM Styles and their Effect on Corporate Performance. Information and Management, 40(5), 403-417. http://dx.doi.org/10.1016/S0378-7206(02)00060-5

Darroch, J. (2005). Knowledge Management, Innovation, and Firm Performance. Journal of Knowledge Management, 9(3), 101-115. http://dx.doi.org/10.1108/13673270510602809

Darroch, J., \& McNaughton, R. (2003). Beyond Market Orientation: Knowledge Management and the Innovativeness of New Zealand firms. European Journal of Marketing, 37(3/4), 572-593. http://dx.doi.org/10.1108/03090560310459096

Davenport, T., \& Prusak, L. (1998). Working Knowledge: How Organizations Manage What They Know. Boston: Harvard Business School Press.

De Geus, A. (1988). Planning as Learning. Harvard Business Review, 88(2), 70-74.

Dimovski, V. (1994). Organizational Learning and Competitive Advantage. PhD Thesis, Cleveland, Ohio.

Francisco, J., \& Guadamillas, F. (2002). A Case Study on the Implementation of a Knowledge Management Strategy Oriented to Innovation. Knowledge and Process Management, 9(3), 162-71. http://dx.doi.org/10.1002/kpm.143 
Garratt, B. (1990). Creating a Learning Organization: A Guide to Leadership, Learning, and Development. New York: Simon \& Schuster.

Gloet, M., \& Terziovski, M. (2004). Exploring the relationship between knowledge management practices and innovation performance. Journal of Manufacturing Technology Management, 15(5), 402. http://dx.doi.org/10.1108/17410380410540390

Gold, A., Malhortra, A., \& Segars, A. (2001). Knowledge Management: An Organizational Capabilities Perspective. Journal of Management Information Systems, 18(1), 185-214.

Gorelick, C., \& Monsou, B. (2005). For Performance through Learning, Knowledge Management is the Critical Practice. The Learning Organization, 12(2), 125-139. http://dx.doi.org/10.1108/09696470510583511

Harry, S. (2006). Knowledge Management, HRM and the Innovation Process. International Journal of Manpower, 24(5), 501-516.

Huber, G. (1991). Organizational Learning: The Contributing Process and the Literatures. Organization Science, 2(1), 88-115. http://dx.doi.org/10.1287/orsc.2.1.88

Jones, A., \& Hendry, C. (1992). The Learning Organization: A Review of Literature and Practice. London: The HRD Partnership.

Jones, G. R. (2000). Organizational Theory (3rd ed.). New York: Prentice Hall.

Kalling, T. (2003). Knowledge Management and the Occasional Links with Performance. Journal of Knowledge Management, 7(3), 67-81. http://dx.doi.org/10.1108/13673270310485631

Ke, W., \& Wei, K. (2006). Organizational Learning Process: Its Antecedents and Consequences in Enterprise System Implementation. Journal of Global Information Management, 14(1), 1-22. http://dx.doi.org/10.4018/jgim.2006010101

Kezar, A. (2005). What Campuses Need to Know About Organizational Learning and the Learning Organization. New Directions for Higher Education, 131, 7-22. http://dx.doi.org/10.1002/he.183

Lapre, M., \& Wassenhove, L. (2001). Creating and Transferring Knowledge for Productivity Improvement in Factories. Management Science, 47(10), 1311-25. http://dx.doi.org/10.1287/mnsc.47.10.1311.10264

Lee, H., \& Choi, B. (2003). Knowledge Management Enablers, Processes, and Organizational Performance: An Integrative View and Empirical Examination. Journal of Management Information Systems, 20(1), $179-228$.

Liao, S., \& Wu, C. (2009). The Relationship among Knowledge Management, Organizational Learning, and Organizational Performance. International Journal of Business and Management, 4(4), 64-76. http://dx.doi.org/10.1016/j.technovation.2007.11.005

Liao, S., Fei, W., \& Liu, C. (2008). Relationship between Knowledge Inertia, Organizational Learning, and Organizational Innovation. Technovation, 28(4), 183-195.

Marques, D., \& Simon, F. (2006). The Effect of Knowledge Management Practices on Firm Performance. Journal of Knowledge Management, 10(3), 143-156. http://dx.doi.org/10.1108/13673270610670911

Massey, A., Montoya-Weiss, M., \& O'Driscoll, T. (2002). Knowledge Management in Pursuit of Performance. MIS Quarterly, 26(3), 269-89. http://dx.doi.org/10.2307/4132333

Mohrman, S., Finegold, D., \& Mohrman, A. (2003). An Empirical Model of the Organization Knowledge System in New Product Development Firms. Journal of Engineering and Technology Management, 20(1\&2), 7-38. http://dx.doi.org/10.1016/S0923-4748(03)00003-1

Mukherjee, A., Lapre, M., \& Wassenhove, L. (1998). Knowledge Driven Quality Improvement. Management Science, 44(11), 35-49. http://dx.doi.org/10.1287/mnsc.44.11.S35

Nazari, K., \& Emami, M. (2012). Knowledge Management: From Theory To Practice. Australian Journal of Business and Management Research, 1(11), 22-30.

Nonaka, I., \& Takeuchi, H. (1995). The Knowledge-Creating Company. New York: Oxford University Press.

Nunnally J., \& Bernstein I. (1994). Psychometric Theory. New York: McGraw-Hill.

Raja, S. R. (2004). Knowledge Management Practices among MSC Status Organizations: A Survey. Proceeding at the 5th International Conference on Knowledge, Culture, and Change Management Organization. University of Aegen, Rhodes, Greece. 
Raja, S. R. (2005). Strategic Linking of Knowledge Management Practices and Human Resource Management Practice among MSC Status Organizations: Enhancing Organization Competitiveness. Proceedings at University Putra Malaysia, Putra World Trading Center, Kuala Lumpur, Malaysia.

Raja, S. R. (2008). The Commercialization of Knowledge Management Practices to K-based Development in Malaysia. Proceedings at the Knowledge Management International Conference and Exhibition, University Utara Malaysia, Langkawi, Kedah, Malaysia.

Rašul, J., Vukšić, V., \& Štemberger, M. (2012). The Impact of Knowledge on Organizational Performance. Economic and Business Review, 14(2), 147-168.

Salina, D., \& Wan Fadzilah, W. (2008). An Empirical Study of Knowledge Management Processes in Small and Medium Enterprises. Communications of the IBIMA, 4(22), 169-177.

Schulz, M., \& Jobe, L. A. (2001). Codification and Tacitness as Knowledge Management Strategies: An Empirical Exploration. Journal of High Technology Management Research, 12(1), 139-65. http://dx.doi.org/10.1016/S1047-8310(00)00043-2

Senge, P. M. (1990). The Fifth Discipline: The Art and Practice of Learning Organization. New York: Currency Doubleday.

Škerlavaj, M., \& Dimovski, V. (2006). Influence of Organizational Learning on Organizational Performance from the Employee Perspective: The Case of Slovenia. Management, 11, 75-90.

Škerlavaj, M., Štemberger, M., Škrinjar, R., \& Dimovski, V. (2007). Organizational Learning Culture-The Missing Link between Business Process Change and Organizational Performance. International Journal of Production Economics, 106(2), 346-367. http://dx.doi.org/10.1016/j.jpe.2006.07.009

Su, K., Hsieh, H., \& Liu, K. (2003). Application of the Learning Organization Paradigm in Engineering Education: An Empirical Research of Universities in Taiwan. World Transactions on Engineering and Technology Education, 2(2), 285-290.

Su, K., Huang, L., \& Hsieh, H. (2004). The Development of a Knowledge Flow Paradigm in Engineering Education: Empirical Research in Taiwanese Universities. World Transactions on Engineering and Technology Education, 3(1), 125-128.

Sveiby, K. E. (1997). The New Organizational Wealth: Managing and Measuring Knowledge-Based Assets. CA: Berrett-Koehler Publishers.

Tahir, S., Basit, T., Haque, M., Mushtaq, A., \& Anwar, C., (2010). Knowledge Management Practices: Role of Organizational Cultural. Proceedings of ASBBS, ASBBS Annual Conference, Las Vegas.

Tanriverdi, H. (2005). Information Technology Relatedness, Knowledge Management Capability, and Performance of Multi-Business Firms. MIS Quarterly, 29(2), 311-34.

Tsang, E. (1997). Organizational Learning and the Learning Organization-A Dichotomy Between Descriptive and Prescriptive Research. Human Relations, 50(1), 73-89. http://dx.doi.org/10.1177/001872679705000104

Van Wiijk, R., Van Den Bosch, F., \& Volberda, H. (2003). Knowledge and Networks. In Easterby-Smith, M., \& Lyles, M. (Eds.), The Handbook of Organizational Learning and Knowledge Management. London: Blackwell Publishing.

Wiig, K. (1997). Knowledge Management: An Introduction and Perspective. Journal of Knowledge Management, 1(1), 6-14. http://dx.doi.org/10.1108/13673279710800682

Wiig, K. M. (2002). Knowledge Management in Public Administration. Journal of Knowledge Management, 6(3), 224-239. http://dx.doi.org/10.1108/13673270210434331

Zack, M., McKeen, J., \& Singh, S. (2009). Knowledge Management and Organizational Performance: An Exploratory Analysis. Journal of Knowledge Management, 13(6), 392-409. http://dx.doi.org/10.1108/13673270910997088

Zhou, A., \& Fink, D. (2003). The Intellectual Capital Web: A Systematic Linking of Intellectual Capital and Knowledge Management. Journal of Intellectual Capital, 4(1), 34-48. http://dx.doi.org/10.1108/14691930310455379 


\section{Copyrights}

Copyright for this article is retained by the author(s), with first publication rights granted to the journal.

This is an open-access article distributed under the terms and conditions of the Creative Commons Attribution license (http://creativecommons.org/licenses/by/3.0/). 